\title{
抗菌薬適正使用に向けた注射抗真菌薬使用届出制の評価
}

\author{
渡邊真一 ${ }^{12}$, 田中亮裕 ${ }^{12}$, 中野夏代 ${ }^{2}$, 宮本仁志 ${ }^{2}$, 中西和雄 ${ }^{2}$, 流鄉昌裕 ${ }^{2}$, \\ 伊東亮治 ${ }^{2}$, 田内久道 ${ }^{2}$, 守口淑秀 ${ }^{1}$, 池川嘉郎 $^{1}$, 末丸克矢 ${ }^{* 1}$, \\ 長谷川 均 ${ }^{2}$, 高田清式 ${ }^{2}$, 相引眞幸 ${ }^{2}$, 安川正貴 ${ }^{2}$, 荒木博陽 \\ 愛媛大学医学部附属病院薬斉部 1 \\ 愛媛大学医学部附属病院感染制御部 2
}

\section{Evaluation of Notification System for Proper Use of Antifungal Drugs}

\author{
Shinichi Watanabe ${ }^{12}$, Akihiro Tanaka ${ }^{12}$, Natsuyo Nakano ${ }^{2}$, Hitoshi Miyamoto ${ }^{2}$, \\ Kazuo Nakanishi ${ }^{2}$, Masahiro Ryugo ${ }^{2}$, Ryoji Itoh ${ }^{2}$, Hisamichi Tauchi' ${ }^{2}$, \\ Toshihide Moriguchi ${ }^{1}$, Yoshiro Ikegawa ${ }^{1}$, Katsuya Suemaru ${ }^{* 1}$, Hitoshi Hasegawa ${ }^{2}$, \\ Kiyonori Takada ${ }^{2}$, Mayuki Aibiki ${ }^{2}$, M asaki Yasukawa $^{2}$ and Hiroaki Araki ${ }^{1}$ \\ Division of Pharmacy, Ehime University Hospital ${ }^{1}$ \\ Division of Infection Control, Ehime University Hospital ${ }^{2}$

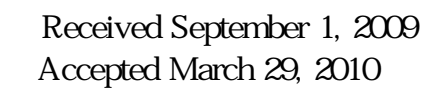

While it is necessary to use antifungal drugs for opportunistic deep mycosis in patients with immune system dy sfunction, the inappropriate use of such drugs needs to be reduced to prevent occurrence of antifungal drug resistance as well as from the pharmacoeconomic viewpoint. In this study, we evaluated a notification system for the proper use of antifungal drugs that was introduced at Ehime University Hospital in January 2008. We investigated changes in antimicrobial use densities $(A \cup D)$ of antifungal drugs, dosage period, number of patients receiving them and average dosage period of antifungal drugs in $\beta$-D glucan negative or unidentified patients from January 2007 to December 2008. A fter the introduction of the notification system, there was a significant decrease in the average monthly AUD of antifungal drugs (from $12.8 \pm 1.8$ to $7.6 \pm$ $1.8 ; p<0.01$ ). The number of patients treated with antifungal drugs for periods of over 12 days and the average dosage period of antifungal drugs in $\beta-D$ glucan negative or unidentified patients also decreased $(p<0.05)$. These results suggested that the notification system was effective in reducing purposeless empirical therapy and ensuring the proper use of antifungal drugs in our hospital.

Key words — antifungal drugs, notification system, proper use of antibiotics, infection control, anti microbial use density, deep mycosis

\section{緒言}

病院内における infection control team(ICT)の役割は院 内感染の防止や感染症のモニタリングなど多岐にわた り，弚の一つに抗菌薬の管理が挙げられる．これまでに 抗 MRSA 薬やカルバペネム薬の使用届出制導入による 有用性が多く報告されているが , 抗真菌薬の適正使用に 関する報告はほとんどされていない年3) . 深在性真菌症 はさまざまなリスクファクターを有する患者に主として 日和見的に発症するため, 抗真菌薬の使用においてはエ ビデンスに基づいた選択や使用法が重要である．また， 耐性化の防止のためには漫然とした使用を避けることが
不可欠である .さらに , 抗真菌薬の適正使用の推進に は, 耐性化防止のみならず, 高額な抗真菌薬が多く，抗 菌薬全体の使用金額に占める割合が高いため，医療経済 的な観点からも抗真菌薬の使用を監視することは重要と 考えられる.愛媛大学医学部附属病院(以下, 当院と略 す)では，不適切な抗真菌薬の長期投与を制御する目的 で2008年 1月より注射薬に関して抗真菌薬長期使用理 由書の届出制を導入した．本研究では，届出制導入前後 の使用実態について抗真菌薬使用量，長期投与患者数， 平均投与日数，抗真菌薬投与患者の平均在院日数および 真菌症のスクリーニング法である $\beta-D$ グルカン陽性患 者 1 人あたりの平均投与日数を指標に長期使用理由書の 届出制を評価したので報告する． 


\section{方法}

1. 運用方法

届出制運用のフローチャートを図 1 に，ならびに長期 使用理由書の樣式を図 2 に示す.当院ではこれまで，抗 MRSA 薬およびカルバペネム薬の不要な長期投与(2週 間以上)を防ぐ目的で 12 日間継続使用している患者を チェックし，長期使用理由書の送付を行ってきた．抗真 菌薬に関しても連続 12 日以上投与された患者を対象 に，薬斉部から長期使用理由書を担当医宛に送付し，回 答を薬剤部へ返送する形式で運用した．送付するための データ集計は，当院の病院情報システム上の情報検索 サーバーにO Oracleデータベースとして保存されている各 種データを，薬剤部クライアント端末よりMS-ACCESS $2000^{\circledR}$ を用いて Open Database Connectivity (ODBC)接続 することにより行った . また，不適切な使用が疑われる 症例については, infection control doctor (ICD)と協議の うえ，担当医に使用状況を聴取するなどの介入を行った 。

\section{2. 使用量の算出}

抗真菌薬長期使用理由書の届出制は 2008年 1月より 開始した . 使用量の調査期間は届出制開始前後 1 年間の 2007 年 1月から 2008年 12 月とした . 各薬剂の使用量 はWHO の提唱する defined daily dose (DDD)を用いた antimicrobial use density (AUD)により算出した .なお， AUD は使用量を特定期間の入院患者延べ日数で除する ことから，入院患者数や在院日数に左右されない使用量 の指標として兴の有用性が示されている ${ }^{4,5)}$. 今回の調査 では, 当院に採用されている抗真菌薬の注射薬(リポ ソーム化アムホテリシンB(L-AMB), ミコナゾール (MCZ) ，ホスフルコナゾール(F-FLCZ)，ボリコナゾール

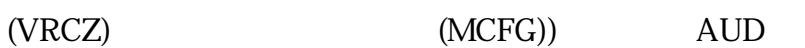
以下の方法で算出した .
$A \cup D=$ 抗菌薬使用量 $(g) /[D D D \times$ 特定期間の入院患者 延べ日数 $] \times 1000$ patient days

長期使用理由書届出制の評価は届出制開始前後での使 用量, 平均在院日数, 長期(12日以上)投与患者数，長期 投与患者 1 人あたり平均投与日数および $\beta-D$ グルカン 陽性患者 1 人あたりの平均投与日数を比較することによ り行った．なお，当院では $\beta-D$ グルカンの測定法はワ コー法を用いており，カットオフ值は $11 \mathrm{pg} / \mathrm{mL}$ とした .

\section{3. 統計}

データは平均値士 標準偏差として示した . 有意差検定 には Mann-Whitney のU 検定を用い, 有意水準は $p<$ 0.05 とした .

\section{結果}

抗真菌薬長期使用理由書の樣式は使用理由，検査結 果，患者状態等に関する項目をチェック形式とした(図 2) . 対象期間中の使用理由書の回収率は 100\% であっ た。

2007 年 1月から 2008 年 12月までの3カ月ごとの抗 真菌薬使用量(AUD)を図 3 に示す . 届出制を開始した 2008年 1月より顕著なAUD の減少がみられ，光の後使 用量は増加なく，ほぼ横ばいであった．1カ月あたりの 平均 AUD は届出制前後で $12.8 \pm 1.8$ から $7.6 \pm 1.8$ へ 有意に $(p<0.01)$ 減少した .なお，1年間の抗真菌薬総投 与患者数は届出制前後で光れ光れ 282 人(男性：169，女 性：113)および221人(男性：139，女性：82)であった． 平均年齢は開始前 $60.3 \pm 20.3$ 歳，開始後 $59.2 \pm 20.9$ 歳 であり, 平均在院日数は開始前 $45.8 \pm 22.3$ 日, 開始後

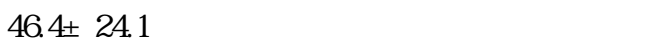

抗真菌薬が 12 日間以上投与された長期投与患者数お よび長期投与患者 1 人あたりの平均投与日数の推移を

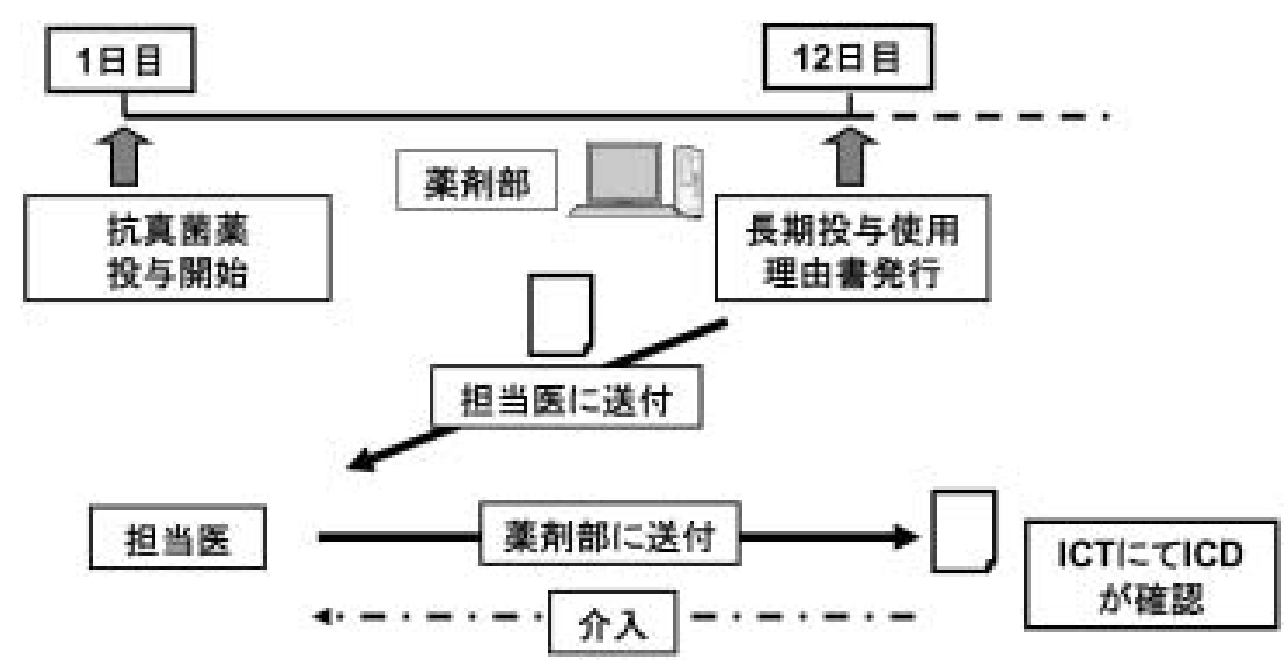

図 1 . 長期使用理由書届出制運用のフローチャート 


$\begin{array}{llll}\text { 病棟 } & \text { 診療科 } & \text { 作成日： 患者氏名 } & \\ \text { 患者 I D } & & \end{array}$

\section{抗真菌薬長期使用理由書}

感染制御部

近年、新規抗真菌薬が次々と臨床応用が可能になり、深在性真菌症の治療薬の選択枝が 増え、様々な領域で深在性真菌症のリスクの高い症例では疑いの段階で経験的治療が開 始することが推奨されています。しかし、抗真菌薬の薬価が高価なこともあり、不必要 な抗真菌菒は避け、適正使用に努めること崜要です。抗真菌薬の不必要な投与圭避け るために抗真菌薬投与の患者様に対して主治医八投与の理由老扔聞きしています。なお、 抗真菌薬長期使用症例はＩＣＴ回診の対象となる場合があります。

$$
\text { 以下のアンタートに答えください。 }
$$

$$
\text { 主治医 (PHS) }
$$

A.

口2週閒以上の投与を行う予定である

口投与終了の予定である

\section{真菌症診断チェックリスト(あてはまる項目にチェックして下さい。)}

B.

口通常無菌部位（血液・胸水・髄液・血管内留置力テ・関節液・骨組織）からの真菌の検出 $\square$ 抗菌薬が無效の感染症

口画像診断にて疑い

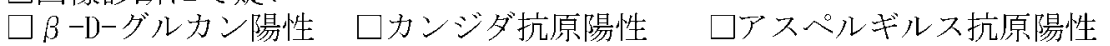

口骨髄移植後

$\square$ 易感染状態の宿主

$\square$ 人工呼吸器使用

口広範囲な外傷、熱傷

\section{口藏器移植後}

$\square$ 中心静脈栄養カテーテル留置

$\square$ その他（

図 2. 抗真菌薬長期使用理由書の樣式

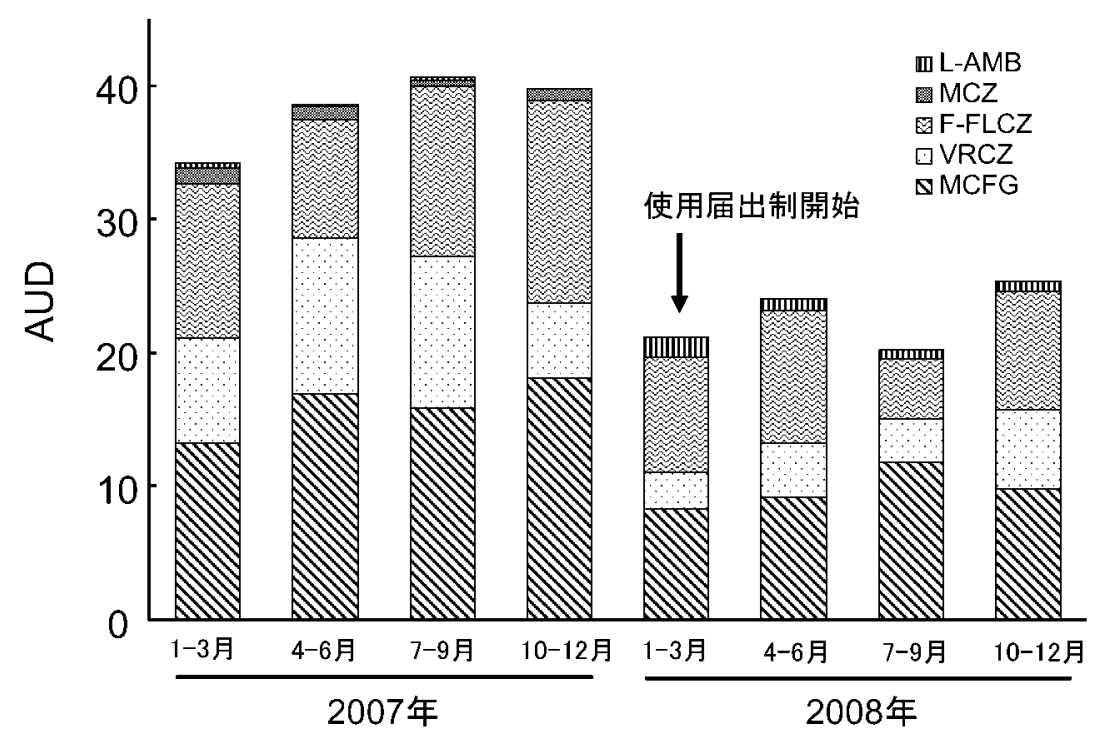

図 3 . 抗真菌薬使用量の推移

データは 3 力月間の使用量を示す . ( $※ M C Z$ は 2007 年 12 月に当院採用中止)

リポソーム化アムホテリシン B : L-A MB , ミコナゾール : MCZ , ホスフルコナゾール :

F-FLCZ , ボリコナゾール : VRCZ , ミカファンギン : MCFG 
図 4 に示す . 長期投与患者数および平均投与日数ともに 減少傾向にあり，届出制開始前(2007 年)と開始後(2008 年)での長期投与患者の平均投与日数を比較すると，23.6 \pm 15.8 日から $18.7 \pm 10.0$ 日へと有意 $(p<0.05)$ に短縮し た . 抗真菌薬が長期投与された患者のうち， $\beta$-D グル カンが末確認(未検出あるいは未検査)の患者を対象とし て届出制前後での平均投与日数を比較した結果, $22.9 \pm$ 14.8日から $17.6 \pm 8.8$ 日へと有意 $(p<0.05)$ な短縮がみら れた . また，抗真菌薬長期投与患者における $\beta$-D グル カン検査実施率は届出制前後で $49.4 \%$ から $58.9 \%$ へと 上昇した(表 1).

\section{考察}

当院ではICTの活動の一環として，これまでに抗 MRSA 薬に関しては使用開始時の届出制を導入し,さ らに抗 MRSA 薬とカルバペネム薬に関しては連続 12 日 間以上投与された患者を対象に，長期使用理由書の届出 制を導入することにより長期投与患者の抑制に対して一
定の効果をあげてきだ). 今回，抗真菌薬に関しても長 期使用理由書届出制を導入することにより，MCFG， VRCZ およびF-FLCZ の使用量が顕著に減少した(図 3). L-A MB のみ使用量の増加がみられたが , 投与症例は少 なく，難治症例のため長期投与に至ったことが原因であ り，不適切な使用ではなかった．一方，抗真菌薬投与患 者の平均在院日数は届出制前後で变化はなく，使用量の 減少による治療期間の延長は認められなかった．した がって, 届出制の導入は抗真菌薬の適正な使用量の制御 に有効であったと考えられる．当院における抗真菌薬長 期使用理由書届出制のシステムは, 回収率 100\% と良好 であり，書式もチェック形式と簡便なものにしたことか ら，医師に対して不要な長期投与を抑制する意識付けが なされた結果と思われる．

今回の抗真菌薬長期使用理由書届出制の取り組みで は, $\beta$-D グルカン值の測定を深在性真菌症発症のスク リーニング法として用いた . 深在性真菌症の診断におい て $\beta$ - D グルカンは抗原検出法のように病原真菌の特定 の属に特異的なものではなく，偽陽性を生じる場合もあ

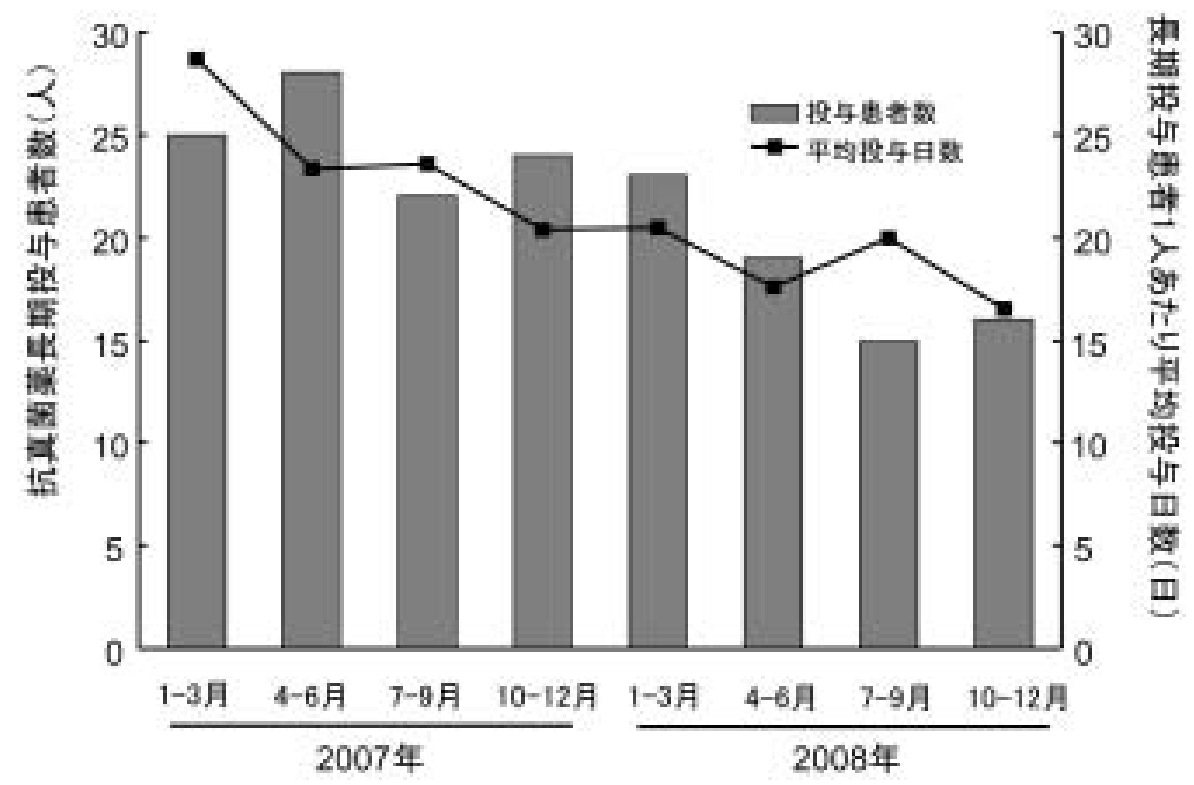

図 4 . 抗真菌薬長期投与患者数および長期投与患者一人あたりの 平均投与日数の推移

表 1 . 抗真菌薬長期投与患者における平均投与日数および $\beta-D$ グルカン検査実施率

\begin{tabular}{|c|c|c|c|c|}
\hline & & 患者数 (人) & 平均投与日数 (日) & $\beta-\mathrm{D} ク ゙ ル カ ン$ 検査率 $(\%)$ \\
\hline \multirow{2}{*}{ 2007年 } & 長期投与患者(全体) & 99 & $23.6 \pm 15.8$ & 49.4 \\
\hline & 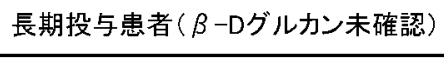 & 77 & $22.9 \pm 14.8$ & - \\
\hline \multirow{2}{*}{ 2008年 } & 長期投与患者(全体) & 73 & $18.7 \pm 10.0^{*}$ & 58.9 \\
\hline & 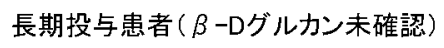 & 56 & $17.6 \pm 8.8^{*}$ & - \\
\hline
\end{tabular}

各年下段は $\beta-D$ グルカン未確認(未検出あるいは未検査)患者における值を示す．

${ }^{*} p<0.05$, Mann-Whitney のU 検定(vs 2007 年) 
り，接合菌症などでは陰性となることが知られている． しかしながら， $\beta$-D グルカン值測定は深在性真菌症の スクリーニング検査として位置づけられており，欧米の ガイドラインでも光の有用性が述べられている ${ }^{7-9)}$. 今 回の調査で, 届出制導入後に $\beta-D$ グルカンが未確認か つ長期投与が行われた患者の平均投与日数に有意な短縮 がみられた .このことは, 経験的投与が長期にわたり行 われていた患者に対する使用量の減少が，兴の要因と なっていることを示唆している．また， $\beta$-D グルカン 検査実施率が届出制導入後に上昇したことから，使用理 由書にチェック項目として $\beta$-D グルカン值の測定を設 けたことが，検査実施への意識向上に有用と考えられる (表 1).

深在性真菌症は免疫不全状態や感染抵抗性減弱状態な ど，宿主状態が不良な場合が多く，確定診断を待てない 場合が多い。したがって, 血液内科領域や藏器移植領域 など，深在性真菌症を発症するリスクの高い症例を扱う 診療科では抗真菌薬の予防投与が行われ，光の他の領域 でも深在性真菌症疑いの段階で経験的治療を行うように 推奖されている.近年では, 確定診断までは得られなく とも，血清診断法など比較的信頼性の高い迅速診断法を 用いて早期に深在性真菌症を臨床診断し，可及的早期に 治療を開始する早期推定治療(early-presumptive therapy) や，真菌の定着が認められた時点で抗真菌薬の投与を開 始し，深在性真菌症の発症を防止しようとする先制攻撃 的治療(preemptive therapy)と呼ばれる概念が浸透してき ている10-12)。しかしながら，エビデンスに基づいた経験 的治療が原則であり，耐性菌出現の抑制や薬剂費削減な どの観点からも，不必要な抗真菌薬の使用は避けるべき である．今回の届出制開始により，2008年の抗真菌薬 の年間使用金額(薬価)は 2007 年と比較して約 2,370 万円 の減少がみられ，経済的側面からも光の有用性が明らか となった．今回の届出制は注射薬を対象に行ったが，今 後は経口薬についても検討が必要と考えられる．

以上のことから，ICT の取り組みとして抗真菌薬使用 量のモニタリングを継続し，適正使用の推進に努めるこ とは重要である．今回の結果から，長期にわたる経験的 投与の期間短縮が示唆されたが, さらなる適正使用のた めには，使用理由書の発行期間短縮も含めた検討が必要 と考えられる．乥してこれら医薬品適正使用に関する情 報は，ICT から院内へ共有されることか望まれる．

\section{引用文献}

1)田中広紀, 熟見正宏, 平林麻里, 並木美加子, 宇賀神和 久, 阿南晃子, 丸茂健治, 田口和三, 菊池敏樹, 長島梧 郎，齋藤正志，管理抗菌薬の使用届出制導入による影響 と評価，日本病院薬斉師会䧱誌，44，1519-1521 (2008).
2) 太田垣昌志 , 抗菌薬適正使用化に向けた特定抗菌薬の使 用届出制と許可制の導入, 日本病院薬剂師会杂隹志, 44 , 121-123 (2008).

3) 大江利治, 阿部佳史 , 抗菌薬の使用状況調査 - 指定抗菌 薬使用届出制度導入の影響一, 日本病院薬斉師会杂隹志, 43 , 1113-1116 (2007).

4) E. Meyer, F. Schwab, P. Gastmeier, H. Rueden, F. D. Daschner, Surveillance of antimicrobial use and antimicrobial resistance in German intensive care units (SARI): a summary of the data from 2001 through 2004, Infection, 34 , 303-309 (2006).

5) 片山歳也，感染制御及び医療安全に貢献する薬斉師の必 要性, 薬学杂隹誌, 127, 1789-1795 (2007).

6) 檜垣宏美, 田中亮裕, 中野夏代, 池川嘉郎, 守口淑秀, 末丸克矢，荒木博陽，適正使用に向けた特定抗菌薬使用 理由書届け出制の評価と抗 MRSA 薬のTDM，愛媛県病 院薬剂師会杂隹誌, 104，13-19(2009).

7)“深在性真菌症の診断・治療ガイドライン 2007”, 深在 性真菌症のガイドライン作成委員会, 協和企画, 東京, 2007 , pp. 36-48.

8) T. J. Walsh, E. J. A naissie, D. W. Denning, R. Herbrecht, D. P. Kontoyiannis, K. A. Marr, V. A. Morrison, B. H. Se gal, W. J. Steinbach, D. A. Stevens, J. A. van Burik, J. R. Wingard, T. F. Patterson, Treatment of aspergillosis: clinical practice guidelines of the Infectious Diseases Society of A merica, Clin. Infect. Dis., 46 , 327-360 (2008).

9) B. De Pauw, T. J. Walsh, J. P. Donnelly, D. A. Stevens, J. E. Edwards, T. Calandra, P. G. Pappas, J. Maertens, O. Lortholary, C. A. Kauffman, D. W. Denning, T. F. Patterson, G. Maschmeyer, J. Bille, W. E. Dismukes, R. Herbrecht, W. W. Hope, C. C. Kibbler, B. J. Kullberg, K. A. Marr, P. Muñoz , F. C. Odds, J. R. Perfect, A. Restrepo, M. Ruhnke, B. H. Segal, J. D. Sobel, T. C. Sorrell, C. Viscoli, J. R. Wingard, T. Zaoutis, J. E. Bennett, Revised definitions of invasive fungal disease from the European Organization for Research and Treatment of Cancer/Invasive Fungal Infections Cooperative Group and the National Institute of A Ilergy and Infectious Diseases Mycoses Study Group (EORTC/MSG) Consensus Group, Clin. Infect. Dis., 46 , 1813-1821 (2008).

10) H. Tanaka, H. Goto, S. Sakaki, Efficacy study of early presumptive therapy (EPT) for deep fungal infection, Jpn. J. Med. Mycol ., 45 , 203-208 (2004).

11) J. Maertens, D. Deeren, D. Dierickx, K. Theunissen, Pre emptive antifungal therapy : still a way to go, Clin. Infect. Dis., 48 , 1042-1051 (2009).

12) C. Cordonnier, C. Pautas, S. Maury, A. V ekhoff, H. Farhat, F. Suarez, N. Dhedin, F. Isnard, L. A des, F. Kuhnowski, F. Foulet, M. Kuentz, P. Maison, S. Bretagne, M. Schwarzinger, Empirical versus preemptive antifungal therapy for high-risk, febrile, neutropenic patients: a randomized, controlled trial, Clin. Infect. Dis., 48 , 1052-1054 (2009). 